\title{
SRI-A Method for Sustainable Intensification of Rice Production with Enhanced Water Productivity
}

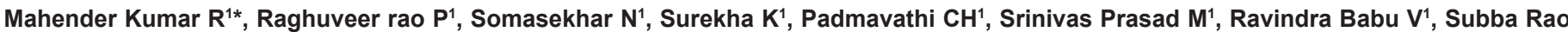
LV1, Latha PC 1 , Sreedevi B ${ }^{1}$, Ravichandran S1, Ramprasad AS ${ }^{1}$, Muthuraman P1, Gopalakrishnan S², Vinod Goud V³ and Viraktamath BC

${ }^{1}$ Directorate of Rice Research (DRR), Hyderabad, India

${ }^{2}$ International Crop Research Institute for Semi Arid Tropics (ICRISAT), India

${ }^{3}$ WWF-ICRISAT Patancheru, Rangareddy Hyderabad, India

\begin{abstract}
Climate change induced higher temperatures will increase crops' water requirements. Every $10^{\circ} \mathrm{C}$ increase in mean temperature, results in $7 \%$ decline in the yield of rice crop. Hence, there is a need to develop water saving technologies in rice which consumes more than $50 \%$ of the total irrigation water in agriculture. System of Rice Intensification (SRI) is one such water saving rice production technology. Experiments were conducted at different locations in India including research farm of Directorate of Rice Research (DRR), Hyderabad, during 2005-10 to assess the potential of SRI in comparison to normal transplanting/Standard Planting (NTP/SP) under flooded condition. SRI recorded higher grain yield (6 to $65 \%$ over NTP) at majority of locations. Long term studies clearly indicated that grain yield was significantly higher (12-23\% and 4-35\% over NTP in Kharif and Rabi seasons, respectively) in SRI (with organic+inorganic fertilizers) while the SRI (with100\% organic manures), recorded higher yield (4-34\%) over NTP only in the Rabi seasons. Even though, SRI resulted in higher productivity, the available nutrient status in soil was marginally higher (10, 42 and $13 \%$ over NTP for N, P and K, respectively) at the end of four seasons. There was a reduction in the incidence of pests in SRI and the relative abundance of plant parasitic nematodes was low in SRI as compared to the NTP. About $31 \%$ and $37 \%$ saving in irrigation water was observed during Kharif and Rabi seasons, respectively in both methods of SRI cultivation over NTP. SRI performed well and consistently reduced requirement of inputs such as seed and water in different soil conditions. SRI method, using less water for rice production can help in overcoming water shortage in future and it can also make water available for growing other crops thus promoting crop diversification.
\end{abstract}

Keywords: System of Rice Intensification (SRI); Methods of rice cultivation; Water saving; Nutrient use efficiency

\section{Introduction}

Rice is the staple food for $65 \%$ population of India. The demand for rice is expected to rise due to increase in population increase $(1.6 \%$ year-1) and reduction in area under rice cultivation in next 15-20 years. Hence, there is a need to increase the productivity of rice to feed the burgeoning population. Water scarcity appears to be one of the major constraints affecting rice production across the globe. More than 80 percent of the fresh water resources in Asia are used for agriculture and about a half of it is used for rice production [1]. Available estimates indicate that fresh water availability in India will be reduced to one-third by 2025 . Therefore, future rice production depends on how we improve the water use efficiency of the rice crop. Reducing amount of water in irrigated rice production has become a matter of global concern and of late, water saving irrigation techniques has received renewed attention [2]. Production of "more rice for every drop of water used" will be a guiding principle for rice cultivation in future. There are several options to improve the water use efficiency in rice production. Zero tillage, Alternate Wetting and Drying (AWD), Aerobic rice, Integrated Crop Management (ICM) and System of Rice Intensification (SRI) are some of the alternative technologies that reduce the requirements of water. SRI among the methods has an edge over other water saving methods as water-saving does not have a yield penalty in this system. Therefore, efforts are being made in many countries to popularize SRI to overcome the challenges of water shortages. System of rice intensification (SRI) management proposes the use of single young seedlings raised in raised bed under aerobic conditions, drastically reduced plant densities (16 hills/m2), keeping fields unflooded and use of a mechanical weeder which aerates the soil, and use of more organic manures, all the practices with the aim of providing optimal growth conditions for the plant, to get better performance in terms of yield and input productivity. The system of rice intensification (SRI) has been promoted for more than a decade as a set of agronomic management practices for rice cultivation that enhances the yield and reduces water requirements [3]. Remarkable progress in the last 50 years in agricultural production and self-sufficiency of food grains in many countries including India; it has been attained at the cost of soil health [4]. Therefore, emphasis should be laid on reducing the use of chemical inputs and to improve input use efficiency. The information on long term effects of organic nutrient application in different methods of rice production (SRI and Normal Transplanting) with regard to water productivity and sustainable rice production under different soil and climatic conditions under India is very meager. Hence, present investigations were carried out to assess SRI-as sustainable intensification of rice production system for enhancing the water productivity.

*Corresponding author: Mahender Kumar R, Directorate of Rice Research, Hyderabad, India, E-mail: kumarrm213@gmail.com

Received February 16, 2013; Accepted February 18, 2013; Published June 20 , 2013

Citation: Mahender Kumar R, Raghuveer rao P, Somasekhar N, Surekha K Padmavathi $\mathrm{CH}$, et al. (2013) SRI- A Method for Sustainable Intensification of Rice Production with Enhanced Water Productivity. Agrotechnol S11: 009. doi:10.4172/2168-9881.S11-009

Copyright: (c) 2013 Mahender Kumar R, et al. This is an open-access article distributed under the terms of the Creative Commons Attribution License, which permits unrestricted use, distribution, and reproduction in any medium, provided the original author and source are credited. 


\section{Materials and Methods}

\section{Experimental site characteristics}

DRR under its All India Co-ordinated Rice Improvement Program (AICRIP) organized multi-location (25 locations) trials (MLT) during 2004-2007 to evaluate SRI method vs. normal transplanting to understand the scientific basis and the merits of the system and to fine tune for wider adaptability and to identify limitations, if any. The treatments included two methods of crop establishment's viz., Normal transplanting (NTP) and System of rice intensification (SRI). Three genotypes viz., variety Krishnahamsa, rice hybrid KRH-2 and a local check variety of the respective location were used. The selected genotypes are widely adopted and promising with higher yield potential with wider adoptability. The details of the locations and soil information are furnished in table 1 . Studies were conducted under identical nutrient management practices across the treatments in different soil condition in split plot design replicated three times at each location (Directorate of Rice Research -D.R.R Progress reports, 2005-2008) (Table 1). Further, experiments were also conducted at the experimental farm of the Directorate of Rice Research, International Crop Research Institute for Semi Arid tropics (ICRISAT) campus $\left(17-53^{\circ} \mathrm{N}\right.$ latitude, $78.27^{\circ} \mathrm{E}$ longitude, $545 \mathrm{~m}$ altitude, with a mean maximum temperature of $32^{\circ} \mathrm{C}$, mean minimum temperature of $20^{\circ} \mathrm{C}$ and mean annual precipitation of $750 \mathrm{~mm}$ ), Hyderabad, India from 2008 to 2010 covering four season-two wet (WS) and two dry seasons (DS) with an integrated rice ecosystem in an undisturbed field lay out with permanent bunds around each plots separated with a plastic sheet to a depth of 1 meter. The experimental field was under rice mono cropping for the past twenty years using inorganic fertilizers only. In SRI and Normal Transplanting methods, the inputs applied were same ( $50 \%$ organic $+50 \%$ inorganic) while in SRI-organic, total nutrients were supplied through organic sources (FYM, Vermicompost and green manure, Gliricidia). Rice varieties with bold grain quality (Sampada) were tested during wet and dry seasons. The local recommended dose of inorganic fertilizers were given at the rate of 100-60-40 kg N, $\mathrm{P}_{2} \mathrm{O}_{5}, \mathrm{~K}_{2} \mathrm{O} /$ ha during WS and 12060-40-10 kg N, $\mathrm{P}_{2} \mathrm{O}_{5}, \mathrm{~K}_{2} \mathrm{O}$ and $\mathrm{Zn} /$ ha during DS through urea, single super phosphate, muriate of potash and Zinc sulphate, respectively. Insect pest incidence was recorded on ten randomly marked hills in each plot as and when the incidence was observed in both the seasons 2009 and 2010. For nematode analyses, soil samples were collected from rhizosphere $(0-15 \mathrm{~cm}$ depth) form three spots from each plot at the time of harvest. Soil collected from three spots in each plot was pooled to make a composite sample. Nematodes were extracted using modified Cobb's sieving and decanting technique from $100 \mathrm{~g}$ soil subsamples taken from each composite sample (Hooper, 1986). Total number of plant-parasitic and free-living microbial feeding nematodes in each sample was counted by observing nematode suspension under stereo zoom microscope. Nematode population densities were expressed as nematodes/100 $\mathrm{g}$ of soil. All the plants in an area of $5 \mathrm{~m} \times 5$ $\mathrm{m}$ for each replicate $\left(25 \mathrm{~m}^{2}\right)$ were harvested (excluding border rows) for determination of yield per unit area and grain yield was adjusted to $14 \%$ seed moisture content. Harvest Index was calculated by dividing dry grain yield by the total dry weight of above ground parts. Soil Chemical properties were evaluated by the wet digestion method of Walkley and Black [5], rapid titration method) for organic carbon (OC\%); modified Kjeldahl method [6] for total $\mathrm{N}\left(\mathrm{kg} \mathrm{ha}^{-1}\right)$, and colorimetric method [7] for available $\mathrm{P}\left(\mathrm{kg} \mathrm{ha}^{-1}\right)$. All the data were statistically analyzed using analysis of variance (ANOVA) procedure of SAS (SAS, 2000) and the significance of the treatment effect was determined using on F-Test and significance between the means of the treatments differentiated based on least significant difference (LSD) at 5\% probability level. Details of management practices followed for SRI and NTP are given in table 2.

\begin{tabular}{|c|c|c|c|c|c|c|c|c|}
\hline \multirow[t]{2}{*}{ Zone } & & \multirow[t]{2}{*}{ Location } & \multirow[t]{2}{*}{ Soil type } & \multirow[t]{2}{*}{ pH } & \multirow[t]{2}{*}{ Varieties (local) } & \multicolumn{3}{|c|}{ Available NPK (kg/ha) } \\
\hline & & & & & & $\mathbf{N}$ & $\mathbf{P}$ & $\mathbf{K}$ \\
\hline \multirow[t]{2}{*}{ Hilly areas } & 1 & Almora & Silty clay loam & 5.5 & VL Dhan-61 & 310 & 25.4 & 210 \\
\hline & 2 & Malan & Silty clay loam & 5.70 & HPR-2143 & 403 & 31 & 177 \\
\hline \multirow[t]{3}{*}{ North western } & 3 & Kapurthala & Clay Loam & 8.5 & PR-115 & - & - & - \\
\hline & 4 & Chatha & Loam & 7.14 & PC-19 & 174 & 15.2 & 140 \\
\hline & 5 & Pantnagar & Silty loam & 8.02 & Pant Dhan-4 & - & 22 & 200 \\
\hline \multirow[t]{11}{*}{ Eastern } & 6 & Jagdalpur & Sandy loam & 6.3 & Swarna & 198 & 10.2 & 236 \\
\hline & 7 & Raipur & Loam & 7.20 & Mahamaya & 205 & 32.5 & 310 \\
\hline & 8 & Varanasi & Sandy loam & 7.30 & ProAgro-6201 & 184.60 & 28.3 & 215 \\
\hline & 9 & Ranchi & Silty loam & 6.10 & IR-64 & 230 & 38.2 & 165 \\
\hline & 10 & Patna & Clay & 7.20 & Rajendra Sweta & 278.00 & 40 & 415 \\
\hline & 11 & Umiam & Sandy loam & - & RCPL-1-87-8 & - & - & - \\
\hline & 12 & Titabar & Clay loam & 5.30 & Ranjit & 212 & 22 & 321 \\
\hline & 13 & Pusa & Silty clay loam & 8.20 & Prabhat & - & - & - \\
\hline & 14 & Karimganj & Clay loam & 5.5 & Ranjit & 250 & 9 & - \\
\hline & 15 & Arundhatinagar & Clay loam & 5.60 & - & 0.13 & 16 & 190 \\
\hline & 16 & Chiplima & Silty loam & 6.40 & Lalat & 245 & 9.3 & 248 \\
\hline \multirow[t]{2}{*}{ Western } & 17 & Nawagam & Sandy loam & 7.33 & GR-11 & - & 94.9 & 554 \\
\hline & 18 & Karjat & Clay loam & 6.5 & Sahyadri-1 & 212 & 22 & - \\
\hline \multirow[t]{7}{*}{ Southern } & 19 & ARI, R' Nagar & Clay loam & 7.8 & M-7 & 310 & 25 & 375 \\
\hline & 20 & Coimbatore & Clay loam & 7.30 & $\mathrm{CO}-47$ & 225 & 17 & 524 \\
\hline & 21 & Aduthurai & Clay loam & 7.09 & ADT-47 & 260.00 & 27 & 350 \\
\hline & 22 & Siruguppa & Clay & 7.7 & IET-16937 & 337 & 25 & 400 \\
\hline & 23 & Karaikal & Clay loam & 7.5 & $\mathrm{ADT}^{\circledR}-45$ & 188 & 16 & 155 \\
\hline & 24 & Maruteru & Clay Loam & - & MTU-100 & - & - & - \\
\hline & 25 & Madya & Silty loam & 7.10 & BR-2655 & 281 & 2.7 & 186 \\
\hline
\end{tabular}

Table 1: Details of the Locations. 


\begin{tabular}{|c|c|c|c|c|c|c|c|}
\hline S.No. & \multicolumn{3}{|l|}{ Practices } & \multicolumn{4}{|c|}{ SRI Method } \\
\hline 1 & \multicolumn{3}{|l|}{ Nursery } & \multicolumn{4}{|c|}{$\begin{array}{l}\text { Uniformly distributed } 5 \mathrm{~kg} / \mathrm{ha} \text { organic man } \\
\text { and irrigated with rose can 3-4 times a day }\end{array}$} \\
\hline 2 & \multicolumn{3}{|c|}{ Seedling age at transplanting } & \multicolumn{4}{|c|}{ 10-12 day old seedling } \\
\hline 3 & \multicolumn{3}{|c|}{ Plant spacing and density } & \multicolumn{4}{|c|}{$\begin{array}{l}\text { One seedling per hill was transplanted in a } \\
\text { of } 25 \mathrm{~cm} \times 25 \mathrm{~cm} \text { and carefully after uprooti }\end{array}$} \\
\hline 4 & \multicolumn{3}{|c|}{ Weed management } & \multicolumn{4}{|c|}{$\begin{array}{l}\text { Four weedings by cono-weeder were perf } \\
\text { to incorporate weeds and aerate the soil }\end{array}$} \\
\hline 5 & \multicolumn{3}{|c|}{ Water management } & \multicolumn{4}{|c|}{$\begin{array}{l}\text { Seedlings were transplanted } 1-2 \mathrm{~cm} \text { deep } \\
\text { without any ponding water. During the veg } \\
\text { were kept saturated (not flooded) and afte } \\
\mathrm{cm} \text { of standing water was maintained on th } \\
\text { before harvest }\end{array}$} \\
\hline \multirow[t]{2}{*}{6} & \multirow{2}{*}{\multicolumn{3}{|c|}{ Nutrient management }} & \multicolumn{4}{|c|}{$\begin{array}{l}\text { For both sets of methods, organic manure } \\
\text { phosphate and muriate potash at the reco } \\
\text { the time of final land preparation, while } \mathrm{N} \\
2 \text { splits }(75 \% \text { at basal and } 25 \% \text { panicle init }\end{array}$} \\
\hline & & & & \multicolumn{4}{|c|}{$\begin{array}{l}\text { In case of SRI organic (method-1) differed } \\
\text { equivalent to the } N \text { dosage applied. No pe }\end{array}$} \\
\hline \multicolumn{8}{|c|}{ Table 2: Crop management practice for comparati } \\
\hline \multicolumn{2}{|c|}{ Locations } & 2004 & & 05 & 2006 & 2007 & Mean \\
\hline \multicolumn{2}{|c|}{ Aduthurai } & 56.6 & & .6 & 18.7 & 92.9 & 45.0 \\
\hline \multicolumn{2}{|c|}{ Rajendranagar } & 20.1 & 9 & & 34.0 & 20.1 & 20.9 \\
\hline \multicolumn{2}{|c|}{ Arundhathinagar } & 41.6 & & 7.0 & 93.4 & 58.9 & 65.2 \\
\hline \multicolumn{2}{|c|}{ Chatha } & - & 5 & & 5.0 & 22.6 & 11.2 \\
\hline \multicolumn{2}{|c|}{ Coimbatore } & 3.1 & & 5.2 & 15.2 & - & 21.5 \\
\hline \multicolumn{2}{|c|}{ Jagdalpur } & 12.3 & 7 & & 1.8 & 2.5 & 6.1 \\
\hline \multicolumn{2}{|l|}{ Karjat } & 4.0 & 9 & & 6.4 & 5.3 & 6.3 \\
\hline \multicolumn{2}{|c|}{ Pantnagar } & 0.3 & - & & 6.8 & 11.4 & 6.2 \\
\hline \multicolumn{2}{|l|}{ Patna } & 55.5 & & 3.9 & 10.6 & 19.6 & 27.4 \\
\hline \multicolumn{2}{|l|}{ Ranchi } & 11.5 & & 5.9 & 16.1 & 15.1 & 14.7 \\
\hline \multicolumn{2}{|c|}{ Siruguppa } & 6.6 & & 4.7 & 36.4 & 24.6 & 23.1 \\
\hline \multicolumn{2}{|c|}{ Titabar } & 16.4 & 8 & & 5.5 & 7.7 & 9.5 \\
\hline \multicolumn{2}{|c|}{ Umiam } & - & & 3.7 & 12.8 & 15.9 & 14.1 \\
\hline \multicolumn{2}{|l|}{ Mean } & 13.7 & & 3.75 & 12.4 & 12.76 & 14.32 \\
\hline
\end{tabular}

Table 3: SRI performance (\% yield increase) over Normal transplanting (NTP) in different locations (Stable yield performance in 13 Locations).

\section{Results and Discussion}

\section{Response of SRI method on grain yield across the locations}

The results of multi location trials (MLTs) clearly indicated that the performance of SRI varied from location to location indicating that response of SRI is location specific. SRI recorded consistently higher grain yield than NTP at half of the locations (10-13). The mean grain yield increase in SRI method was in the range of 6 to $65 \%$ as compared to NTP (Table 3). Out of 98 instances 73 times SRI recorded higher grain yield $(\mathrm{kg} / \mathrm{ha})$ over Normal transplanting with an average increase grain yield of $19.6 \%$. The increase in grain yield under SRI could attribute to profuse tillering (19.1\%). Panicles $\mathrm{m} 2$ gave significant relationship with grain yield and contributed for higher yield in SRI over NTP practice but no significant with panicle weight (Figure 1). Further, SRI method improved soil aeration achieved through the soil disturbance by cono weeder operation, in addition to effective weed suppression [8-11], Thiyagarajan et al. and Bouman et al. [12,13] are also reported similar factors contributing for higher yield in SRI method. The performance of hybrid was superior over high yielding varieties due to better tillering ability of the hybrids at most of the locations. The results of the long term comparative studies of SRI $v s$. NTP clearly indicated superiority of SRI (Table 4). Grain Yield ranged from $3.92 \mathrm{t} /$ ha to $5.41 \mathrm{t} /$ ha in SRI-organic, 5.34 to $6.73 \mathrm{t} / \mathrm{ha}$ in SRI as compared to 4.97 to $5.17 \mathrm{t} / \mathrm{ha}$ in NTP. The NTP recorded 7 and $23 \%$ lower yield than

\section{Normal transplanting (NTP)}

$30 \mathrm{~kg} / \mathrm{ha}$ in an area of $1000 \mathrm{~m}^{2}$ and grown in flooded situation

30-35 day old seedling

of $20 \times 15 \mathrm{~cm}$

Hand and manual weeding twice at 20 and 35 DAT

Seedlings are transplanted $3-5 \mathrm{~cm}$ deep into a puddle field with 5-6 cm pounded water, and same level was maintained during the vegetative stage. After $P$ I stage 2-3 cm of standings water was kept on the field and drained 15 days before harvest 
Relationship of \%increase in yield of SRI over $\mathrm{Sp}$ on $\%$ increase in panicles of SRI over SP in 4 years

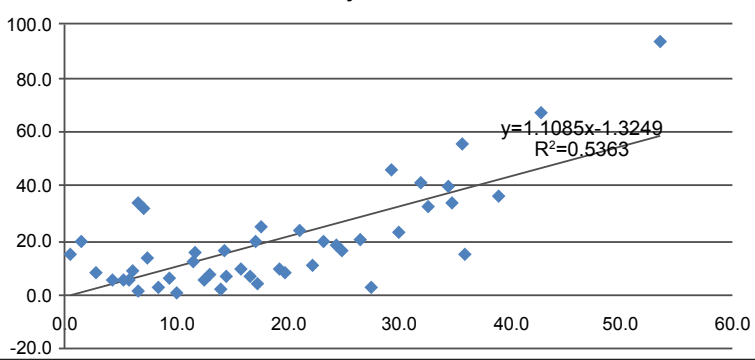

$\mathrm{R}=.732 * * ;$ Note $-\%$ Increase in grain yield SRI over standard Normal Transplanting practice is related to $\%$ increase in panicles/sq.m of SRI over standard practice.
Relationship of \%increase in yield of SRI over Sp on \% increase in PW of SRI over SP in 4

years

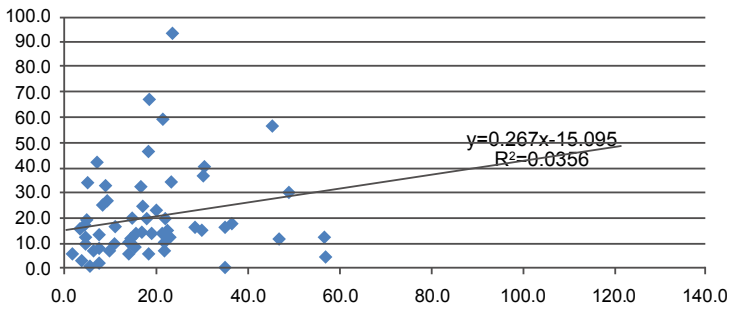

$\mathrm{R}=.187 \mathrm{~ns} ; \%$ increase in panicle wt has no relationship with \% increase in grain yield of SRI over standard Practice

Figure 1: Relationship of \% increase in yield of SRI over NTP on increase in panicles $\mathrm{m}^{2}$ and panicle weight of SRI over NTP ( 4 years 2004-05 to 2007-08)

\begin{tabular}{|c|c|c|c|c|c|c|c|c|c|c|c|c|}
\hline & \multicolumn{3}{|c|}{ Total N (ppm) } & \multicolumn{3}{|c|}{ Available P (ppm) } & \multicolumn{3}{|c|}{ Available K (ppm) } & \multicolumn{3}{|c|}{ OC (\%) } \\
\hline & Kharif & Rabi & & Kharif & Rabi & & Kharif & Rabi & & Kharif & Rabi & \\
\hline Treatment & 08,09 & 08,09 & Mean & 08,09 & 08,09 & Mean & 08,09 & 08,09 & Mean & 08,09 & 08,09 & Mean \\
\hline SRI-Organic & 782 & 880 & 831 & 66 & 64 & 65 & 78 & 109 & 94 & 1.26 & 1.27 & 1.27 \\
\hline SRI (Org+inorg) & 782 & 875 & 829 & 60 & 63 & 61 & 92 & 94 & 93 & 1.2 & 1.17 & 1.19 \\
\hline NTP & 739 & 835 & 787 & 54 & 60 & 57 & 75 & 65 & 70 & 1.18 & 1.17 & 1.18 \\
\hline LSD (0.05) & 172.3 & 113.9 & & 11.2 & 8.2 & & 29.4 & 58.5 & & 0.103 & 0.191 & \\
\hline
\end{tabular}

Table 5: Comparison of available nutrient status as influenced by SRI and NTP.

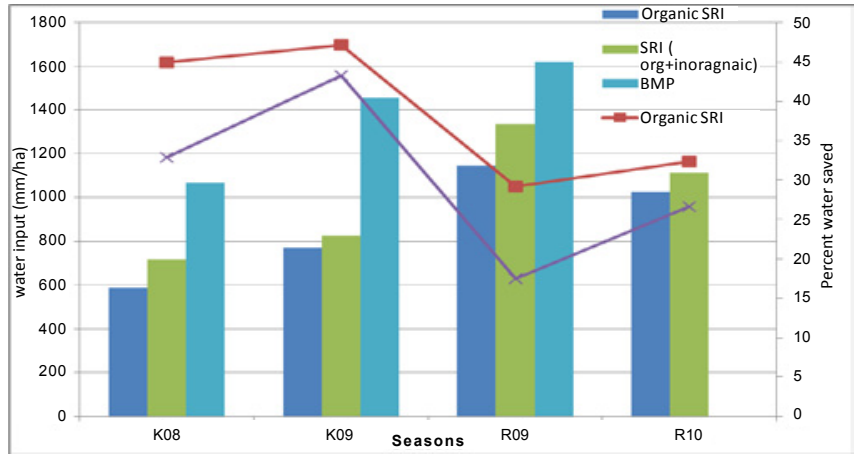

Figure 2: Water input and percent water saving in different methods of crop establishment.

\section{Saving in water}

Irrigation water inputs for different methods of rice cultivation were recorded using digital water meters during the crop seasons indicated that the water saving in SRI ranged from $17-47 \%$ (Figure 2 and Table 5). Both the SRI-organic and SRI-organic+inorganic received significantly lower irrigation water compared to NTP in all the four seasons. SRI saved nearly $25 \%$ irrigation water without any penalty on yield compared to conventional transplanting [20]. Using intermittent irrigation, Thiyagarajan et al. [16] reported water saving of 50\% in SRI over the traditional flooding without any adverse effect on grain yield. Thus, it can be concluded that in the SRI method, irrigation use efficiency was higher over the conventional method of rice cultivation [17].

\begin{tabular}{|c|c|c|c|c|c|}
\hline \multirow[t]{2}{*}{ Season } & \multirow[t]{2}{*}{ Treatment } & \multicolumn{4}{|c|}{ Water Parameters } \\
\hline & & $\begin{array}{l}\text { Water } \\
\text { input } \\
\text { (m³/ha) }\end{array}$ & $\begin{array}{l}\text { Water } \\
\text { productivity } \\
\left(\mathrm{kg} \text { grain } / \mathrm{m}^{3}\right)\end{array}$ & $\begin{array}{l}\text { Litres } \\
\text { per kg } \\
\text { grain }\end{array}$ & $\begin{array}{l}(\%) \text { water } \\
\text { saved } \\
\text { over NTP }\end{array}$ \\
\hline \multirow{4}{*}{\begin{tabular}{|l|} 
Wet season \\
08 (Kharif)
\end{tabular}} & SRI-Organic & 5885.2 & 0.576 & 1736 & 44.90 \\
\hline & SRI (Org+inorganic) & 7167.9 & 0.731 & 1368 & 32.89 \\
\hline & NTP & 10680.1 & 0.439 & 2277 & \\
\hline & L.S.D (0.05\%) & 734 & & & \\
\hline \multirow{4}{*}{$\begin{array}{l}\text { Dry season } \\
\text { 08-09 (Kharif) }\end{array}$} & SRI-Organic & 11466.2 & 0.323 & 3099 & 29.22 \\
\hline & SRI (Org+inorganic) & 13365.9 & 0.395 & 2531 & 17.50 \\
\hline & NTP & 16200.9 & 0.265 & 3776 & \\
\hline & L.S.D (0.05\%) & 1031 & & & \\
\hline \multirow{4}{*}{$\begin{array}{l}\text { Dry season } \\
\text { 08-09 (Rabi) }\end{array}$} & SRI-Organic & 7703.6 & 0.707 & 1414 & 47.10 \\
\hline & SRI (Org+inorganic) & 8268 & 0.658 & 1520 & 43.22 \\
\hline & NTP & 14562.2 & 0.360 & 2779 & \\
\hline & L.S.D (0.05\%) & 1326 & & & \\
\hline \multirow{4}{*}{$\begin{array}{l}\text { DRY season } \\
\text { 09-10 (Rabi) }\end{array}$} & SRI-Organic & 10254.8 & 0.792 & 1263 & 32.39 \\
\hline & SRI (Org+inorganic) & 11125.3 & 0.734 & 1362 & 26.65 \\
\hline & NTP & 15168.1 & 0.399 & 2507 & \\
\hline & L.S.D (0.05\%) & 1328 & & & \\
\hline
\end{tabular}

Table 6: Comparison of water inputs and productivity as influenced by SRI organic SRI organic+inorganic and NTP.

\section{Soil nutrient status}

Changes in soil fertility parameters (mean of two seasons) at the end of each year (WS 08-09 and DS 09-10) were monitored and presented 
in table 6. After two years, except the available $\mathrm{N}$, all the soil properties were influenced significantly by the methods of crop establishment. SRI either organic or organic+inorganic recorded significantly higher values of available $\mathrm{N}(828-831 \mathrm{~kg} / \mathrm{ha}$ ) phosphorus (61-65 kg/ha) and potassium $(93-93.5 \mathrm{~kg} / \mathrm{ha})$. Compared to initial soil values, there was an increase in SOC, available N, P, K and Zn by $35,10,42,13$ and $26 \%$ with organics, respectively, at the end of two years. Comparable increases in available $\mathrm{N}, \mathrm{P}$ and $\mathrm{K}$ through addition of organic materials was reported by Pathak et al. [21] and Singh et al. [22]. Superior soil fertility status on organic farms compared to soils fertilized with chemical fertilizers was reported by Sharma and Singh [14]. They reported that higher carbon and nitrogen mineralization rates and soluble carbon content in organically managed soils indicate that sufficiently higher amounts of available nutrients are made available to the crop.

\section{Pests dynamics in SRI}

The pest incidence data indicated that yellow stem borer damage was high at all stages of crop growth period and its damage (dead hearts) was low under SRI (7.0\%) as compared to NTP (11.4\%). However, at reproductive stage, the damage (white ear heads) of yellow stem borer was high in SRI $(28.3 \%)$ than NTP $(21.2 \%)$. The data collected from farmers through survey indicated that in general, SRI had low pest incidence resulting in lower or no-pesticide application and thus gave higher benefit cost ratio (1.77 and 1.76) than NTP [23]. Similar results of low pest incidence in rice grown under SRI due to vigorous and healthy growth of plant coupled with wider spacing has been reported by Padmavathi et al. and Gasparillo [24,25].

\section{Influence of SRI on soil nematodes}

Transition from normal transplanting system to SRI significantly alters the composition of soil biota with a gradual shift towards the species that prefer upland or aerobic environment $[1,26]$. Investigations on the impact of SRI practices on soil nematodes (which include both harmful plant parasitic nematodes that inflict serious yield losses and beneficial microbial feeding nematodes that promote plant growth by enhancing organic matter decomposition and nutrient cycling) revealed that the abundance of Plant Parasitic Nematodes (PPN) and microbial feeding nematodes (MFN) were significantly higher under SRI as compared to the NTP system. However, the relative abundance of PPN was observed to be low (0.58) in SRI as compared to that of NTP (0.64) system. In contrast to this, the relative abundance of MFN was significantly higher (0.42) in SRI as compared to the NTP (0.36). The PPN community in these experimental plots was dominated by relatively less pathogenic species like rice root nematode (Hirschmanniella spp.) and other ectoparasitic nematodes $[27,28]$. This may be the reason for higher yields in SRI despite increase in the abundance of plant parasitic nematodes. However, it is possible that the effects of SRI management can be negative in areas where there are inherent populations of more damaging nematode species like root-knot nematode (Meloidogyne graminicola). Significantly lower rice yield under SRI as compared to that in NTP as a consequence of rapid buildup of root-knot nematode Meloidogyne graminicola was reported in other studies [29]. Farmers are to be cautioned to monitor carefully for parasitic nematodes when adopting SRI.

\section{Conclusion}

Understanding how to produce more rice with higher factor productivity and in ways that are environmentally friendly and socially more beneficial is the main focus of research in recent years. SRI system which facilitates production of more rice with less quantity of inputs such as water, seed and chemical fertilizers is one of the promising approaches in this direction. Our results have clearly demonstrated that the increase in productivity with SRI based on concomitant increase in factor productivity is possible under certain situations. SRI, however, is a methodology that continues to raise more questions than we have sufficient answers for it. Therefore, there is a need for collaborative research studies to help examine systematically the opportunities that SRI method is opening up for its wider adoptability to benefit the farming community in India where large percentage of farmers are mainly small or marginal farmers and depends primarily on rice cultivation for their lively hood.

\section{References}

1. Anas I, Rupela OP, Thiyagarajan TM, Uphoff N (2011) A review of studies on SRI effects on beneficial organisms in rice soil rhizospheres. Paddy and Water Environment 9: 53-64.

2. Bouman BAM, Tuong TP (2001) Field water management to save water and increase its productivity in irrigated lowland rice. Agricultural Water Management 49: 11-30.

3. Satyanarayana A, Thiyagarajan TM, Uphoff N (2007) Opportunities for wate saving with higher yield from the system of rice intensification. Irrigation Science 25: 99-115.

4. Saravana Pandian P, Subramanian S, Paramasivam P, Kumaraswamy K (2005) Organic farming in sustaining soil health - A review. Agri Rev 26: 141-147.

5. Walkley A, Black IA (1934) An Examination of the Degtjareff Method fo Determining Soil Organic Matter, and A Proposed Modification of the Chromic Acid Titration Method. Soil Sci 37: 29-37.

6. Dalai RC, Sahrawat KL, Myers RJK (1984) Inclusion of nitrate and nitrite in the Kjeldahl nitrogen determination of soils and plant materials using sodium thiosulphate. Commun Soil Sci Plant Anal 15: 1453-1461.

7. Olsen SR, Cole CV, Watanable FS, Dean LA (1954) Estimation of available phosphorus in soils by extraction with sodium bicarbonate. US Dept Agri 939.

8. Directorate of Rice Research (2005) Progress Report of Crop Production (Agronomy, Soil Science and Plant Physiology) - 2004. (Vol. 3), All India Coordinate Rice Improvement Program (ICAR), Directorate of Rice Research, Hyderabad, India.

9. Directorate of Rice Research (2006) Progress Report of Crop Production (Agronomy, Soil Science and Plant Physiology) - 2005. (Vol. 3), All India Coordinate Rice Improvement Program (ICAR), Directorate of Rice Research Hyderabad, India.

10. Directorate of Rice Research (2007) Progress Report of Crop Production (Agronomy, Soil Science and Plant Physiology) - 2006. (Vol. 3), All India Coordinate Rice Improvement Program (ICAR), Directorate of Rice Research Hyderabad, India.

11. Directorate of Rice Research (2008) Progress Report of Crop Production (Agronomy, Soil Science and Plant Physiology) - 2007. (Vol. 3), All India Coordinate Rice Improvement Program (ICAR), Directorate of Rice Research Hyderabad, India.

12. Thiayagarajan TM, Velu V, Ramasamy S, Durgadevi D, Govindarajan K, et al. (2002) Effects of SRI practices on hybrid rice performance in Tamil Nadu, India p: 119-127.

13. Bouman BAM, Hengsdijk H, Hardy B, Bindraban PS, Tuong TP, et al. (2002) Water-wise rice production. International Rice Research Institute (IRRI) and Plant Research International, Manila, Philippines.

14. Sharma PD, Singh $\mathrm{M}(2004)$ Problems and prospects of Organic farming Bulletin of the Indian Society of Soil Science 22: 14-41.

15. Seshu DV, Cady FB (1984) Response of rice to solar radiation and temperature estimated from International yield trials. Crop Science 24: 649-654.

16. Thiyagarajan TM, Hengsdijk H, Bindraban PS (2005) Transitions in Agriculture for Enhancing Water Productivity: Proceedings of an International Symposium Held in Killikulam, Tamil Nadu, India.

17. Namara R, Bossio D, Weligamage P, Herath I (2008) The practice and effects of the System of Rice Intensification (SRI) in Sri Lanka. Qtly J Intl Agric 47: 5-23.

18. Uphoff N (2003) Higher yields with fewer external inputs? The system of 
Citation: Mahender Kumar R, Raghuveer rao P, Somasekhar N, Surekha K, Padmavathi CH, et al. (2013) SRI-A Method for Sustainable Intensification of Rice Production with Enhanced Water Productivity. Agrotechnol S11: 009. doi:10.4172/2168-9881.S11-009

rice intensification and potential contributions to agricultural sustainability. International Journal of Agricultural Sustainability 1: 38-50.

19. Uphoff N (2005) Possible explanations for the productivity gains achieved with the system of rice intensification (SRI). Transitions in agriculture for enhancing water productivity. Proceedings of the International symposium on Transitions in agriculture for enhancing water productivity. Killikulam, Tamil Nadu, India.

20. Thakur AK, Uphoff N, Antony E (2009) An Assessment of Physiological Effects of System or Rice Intensification (SRI) Practices compared with recommended rice cultivation practices in India. Expl Agric p: 1-22.

21. Pathak H, Kushwala, JS, Jain MC (1992). Eyahiation of Manurial value of Biogas spent slurry composted with Dry Mango leaves, wheat straw and Rock Phosphate on wheat crop. J Ind Society Soil Sci 40: 752-757.

22. Singh Y, Singh B, Ladha JK, Khind CS, Khera TS, et al. (2004) Effects of Residue Decomposition on Productivity and Soil Fertility in Rice-Wheat Rotation. Soil Sci Soc Amer J 68: 854-864.

23. Choudhury BU, Singh AK, Bouman BAM (2005) Effect of establishment techniques on yield, crop water relationship in rice and wheat. Transitions in Agriculture for Enhancing Water Productivity: Proceedings of an International Symposium held in Killikulam, Tamil Nadu, India.
24. Padmavathi Ch, Mahender Kumar R, Ravindra A, Lingaiah R (2008) Influence of $\mathrm{SRI}$ on pesticide usage in rice. Extended Summaries $-3^{\text {rd }}$ National Symposium, System of Rice Intensification in India. Coimbatore, Tamil Nadu, India.

25. Gasparillo R (2002) SRI experiences in the Philippines. International Conference on "Assessments of the System of Rice Intensification (SRI). Sanya, China.

26. Gani A (2004) Opportunities for rice self sufficiency in Indonesia with the system of rice intensification. Abstracts on World Rice Research Conference, Tokyo Tsukuba, Japan.

27. Randriamiharisoa R, Barison J, Uphoff N (2006) Soil biological contributions to the System of Rice Production. Biological Approaches to Sustainable Soil Systems. CRC Press, Boca Raton, FL, USA

28. Kumar RM, Surekha K, Padmavathi Ch, Subba Rao LV, Ravindrababu V, et al (2011) System of Rice Intensification-enhancing input use efficiency. Technical Bulletin No. 58/2011. DRR, Hyderabad, India.

29. Sooksa-Nguan T, Thies JE, Gypmantsiri P, Boonkerd N, Teaumroong N (2009) Effect of rice cultivation system on nitrogen cycling and nitrifying bacterial community structure. Appl Soil Ecol 43: 139-149. 